\title{
Prevalence of yeasts in the oral cavity of children treated with inhaled corticosteroids
}

\section{Prevalência de leveduras na cavidade bucal de crianças tratadas com corticosteróides inalados}

\author{
Edson Yukio Komiyama* \\ Patrícia Monteiro Ribeiro** \\ Juliana Campos Junqueira*** \\ Cristiane Yumi Koga-Ito**** \\ Antonio Olavo Cardoso Jorge*****
}

\begin{abstract}
The aim of this study was to observe the prevalence of Candida spp. in the oral cavity of children undergoing treatment with inhaled corticosteroids. Thirty children treated with inhaled corticosteroids and thirty control children were studied. Saliva samples were collected through oral rinses with phosphate buffered saline (PBS). The samples were plated on Sabouraud's dextrose agar and incubated at $37^{\circ} \mathrm{C}$ for $48 \mathrm{~h}$. After this period, the number of colony-forming units per $\mathrm{ml}(\mathrm{cfu} / \mathrm{ml})$ of saliva was calculated. The isolates were identified by phenotypic characterization. Candida spp. was isolated from $43.33 \%$ of the samples of children treated with corticosteroids, with a mean of $780 \mathrm{cfu} / \mathrm{ml}$ of saliva, and from $30 \%$ of the samples of the control group, with a mean of $560 \mathrm{cfu} / \mathrm{ml}$ of saliva. No significant statistical difference was observed between the groups. C. albicans was the prevalent species in both groups, followed by C. guilliermondii, C. parapsilosis and C. stellatoidea. Furthermore, Rhodotorula rubra and C. lusitaniae were also isolated from the treated group. We concluded that there was no significant increase in the prevalence and number of Candida spp. in the oral cavity of children treated with inhaled corticosteroids.

DESCRIPTORS: Candida; Candida albicans; Adrenal cortex hormones; Asthma.
\end{abstract}

RESUMO: O objetivo deste trabalho foi verificar a prevalência de Candida spp. na cavidade bucal de crianças tratadas com corticosteróides inalados. Foram estudadas 30 crianças usuárias de corticosteróides inalados e 30 crianças controle. A coleta de saliva foi realizada através de enxágües bucais com solução fisiológica tamponada (PBS). As amostras foram semeadas em ágar Sabouraud dextrose e incubadas a $37^{\circ} \mathrm{C}$ por 48 horas. A seguir, foi realizada a contagem de unidades formadoras de colônias por $\mathrm{ml}(\mathrm{ufc} / \mathrm{ml})$ de saliva, e as cepas isoladas foram identificadas por caracterização fenotípica. Foram encontradas leveduras do gênero Candida em 43,33\% dos pacientes usuários de corticosteróides, com média de $780 \mathrm{ufc} / \mathrm{ml}$ de saliva, e em 30\% do grupo controle, com média de $560 \mathrm{ufc} / \mathrm{ml} \mathrm{de}$ saliva, não ocorrendo diferença estatisticamente significante entre os grupos. C. albicans foi a espécie prevalente em ambos os grupos, seguida por C. guilliermondii, C. parapsilosis e C. stellatoidea. No grupo usuário de corticosteróide, verificou-se também a presença de Rhodotorula rubra e $C$. lusitaniae. Concluiu-se que não houve aumento significante na presença e na quantidade de leveduras do gênero Candida na cavidade bucal de crianças tratadas com corticosteróides inalados.

DESCRITORES: Candida; Candida albicans; Corticosteróides; Asma.

\section{INTRODUCTION}

Candida species are human pathogens related to superficial lesions, especially in the oral mucosae. The isolation of Candida from the oral cavity does not imply a disease, since the prevalence of this fungus in healthy adults is from 3 to $48 \%$, and the average prevalence in children is from 45 to $65 \%{ }^{17}$. Candida albicans is the most frequently isolated species from the human oral cavity, but other species have also been isolated, including $C$. glabrata, C. tropicalis, C. kefyr, C. parapsilosis, C. krusei and C. guilliermondii ${ }^{25}$.

The mechanism by which these fungi can cause oral candidosis include their ability to adhere to mucosae, to form pseudohyphae and to secrete histolytic enzymes ${ }^{3,13}$. The defense of the oral cavity against Candida is attributed to nonspecific immune mechanisms such as mucosae integrity, leukocytes, macrophages and saliva components,

\footnotetext{
*Graduate Student; **MSc Student; ***PhD Student; ****Assistant Professor; *****Chairman, Professor - Department of Bioscience and Oral Diagnosis, School of Dentistry of São José dos Campos, São Paulo State University.
} 
Komiyama EY, Ribeiro PM, Junqueira JC, Koga-Ito CY, Jorge AOC. Prevalence of yeasts in the oral cavity of children treated with inhaled corticosteroids. Braz Oral Res 2004;18(3):197-201.

and to specific immune mechanisms, including antibodies and cell-mediated immunity ${ }^{17}$.

Oral candidosis has been described as one of the side effects of the therapy with inhaled corticosteroids $^{4,12,19,23}$, which have anti-inflammatory properties and are often used for the symptomatic treatment of asthma in adults and children ${ }^{5,23,24}$. The incidence of oropharyngeal candidosis in patients treated with inhaled corticosteroids varies between 0 and $77 \%$, mainly because of the different diagnosis criteria used ${ }^{4,22,27}$.

Studies on the deposition of corticosteroid sprays on the tissues revealed that approximately $10 \%$ of the inhaled medicine remains in the lungs. The remaining percentage is deposited on the oropharyngeal mucosa, where the drug can cause many effects before being absorbed ${ }^{12}$. The local side effects of inhaled corticosteroids, besides oropharyngeal candidosis, include cough, hoarseness, dysphonia and perioral dermatitis ${ }^{2,4}$. Candidosis probably occurs because these substances cause immunosuppression, which interferes with the cell-mediated immunity and cause an increase in the quantity of glucose in the saliva, which, in turn, can stimulate the growth of Candida ${ }^{4}$.

Toogood et al. ${ }^{22}$ (1980) reported cultures positive for Candida spp. in $60 \%$ of the patients treated with inhaled corticosteroids. The incidence of oral candidosis was between 4 and 13\% in adults and $1 \%$ in children and these rates varied according to the dose and frequency of use of the medication. On the other hand, Shaw, Edmunds ${ }^{20}$ (1986) isolated Candida albicans from the oral cavity of $29 \%$ of the healthy children studied and of $45 \%$ of the children treated with inhaled beclomethasone. These data suggest a high incidence of Candida in users of inhaled corticosteroids regardless of the dose used. Therefore, the purpose of this work was to observe the prevalence of yeasts of the Candida genus in the oral cavity of children treated with inhaled corticosteroids, comparing the results with a control group.

\section{MATERIALS AND METHODS}

Sixty children, between 4 and 12 years old, were included in the present study. Thirty of these children were users of inhaled corticosteroids for the treatment of symptomatic asthma (Table 1). None of the selected patients were diabetic or used antibiotics or antifungal for a minimal period of 60 days before the collection of the samples. The patients were under treatment at the São José
TABLE 1 - Chemical names and daily dose of inhaled corticosteroids used by the patients selected for this study.

\begin{tabular}{l|c|c}
\hline \hline \multirow{2}{*}{$\begin{array}{l}\text { Chemical name of } \\
\text { the corticosteroid }\end{array}$} & Dose/day & $\begin{array}{c}\text { Number of } \\
\text { patients }\end{array}$ \\
\hline \multirow{2}{*}{$\begin{array}{l}\text { Fluticasone } \\
\text { propionate }\end{array}$} & $100 \mu \mathrm{g}$ & 4 \\
\cline { 2 - 3 } & $250 \mu \mathrm{g}$ & 2 \\
\cline { 2 - 3 } & $500 \mu \mathrm{g}$ & 1 \\
\hline \multirow{3}{*}{$\begin{array}{l}\text { Beclomethasone } \\
\text { dipropionate }\end{array}$} & $150 \mu \mathrm{g}$ & 1 \\
\cline { 2 - 3 } & $200 \mu \mathrm{g}$ & 2 \\
\cline { 2 - 3 } & $800 \mu \mathrm{g}$ & 12 \\
\cline { 2 - 3 } & $1,200 \mu \mathrm{g}$ & 4 \\
\hline Budesonide & $400 \mu \mathrm{g}$ & 3 \\
\hline \hline
\end{tabular}

Clinic, São José dos Campos, SP, Brazil. The adult responsible for the child was informed about the purpose of the present study and in case of agreement, signed the informed consent form. This work was previously evaluated and approved by the Research Ethics Committee of the School of Dentistry of São José dos Campos, São Paulo State University.

Saliva samples were collected through oral rinses with a $10 \mathrm{ml}$ sterile physiological solution $(0.85 \% \mathrm{NaCl}$, Synth, SP, Brazil) and buffered with a phosphate solution (PBS - 0.1 M and $\mathrm{pH} 7.2$ ) for 30 seconds. Each sample was centrifuged for 10 minutes $(2,000 \mathrm{xg})$ and the supernatant was discarded. The pellet was resuspended in $2.5 \mathrm{ml}$ of PBS (Sigma, SP, Brazil) and agitated in a mixer (Vortex, Marconi, Piracicaba, SP, Brazil) for 30 seconds.

An aliquot of $0.1 \mathrm{ml}$ of the suspension was plated in Sabouraud dextrose agar (Difco, Detroit, USA) with chloramphenicol (Carlo Erba, Rio de Janeiro, Brazil; $0.1 \mathrm{mg} / \mathrm{ml}$ ), incubated at $37^{\circ} \mathrm{C}$ for 48 hours, and at room temperature for five extra days. The yeast colonies were counted and the number of colony-forming units per $\mathrm{ml}(\mathrm{cfu} / \mathrm{ml})$ of saliva was calculated. Yeast colonies were confirmed microscopically by Gram-stained smear and subcultured in Sabouraud dextrose agar for identification. The samples were identified by observing the germinative tubes in sterile rabbit serum, the presence of hyphae and chlamydospores in 
Komiyama EY, Ribeiro PM, Junqueira JC, Koga-Ito CY, Jorge AOC. Prevalence of yeasts in the oral cavity of children treated with inhaled corticosteroids. Braz Oral Res 2004;18(3):197-201.

cornmeal Tween 80 agar (Difco, Detroit, USA) and carbohydrate fermentation and assimilation ${ }^{18,26}$. The urease test was used for the identification of Rhodotorula ${ }^{10}$.

Data were analysed statistically by chi-square $\left(\chi^{2}\right)$, Mann-Whitney and Pearson's correlation tests, with a $5 \%$ significance level.

\section{RESULTS}

Candida spp. was isolated from the oral cavity of $43.33 \%$ of the patients treated with corticosteroids and of $30 \%$ of the control group. However, no significant statistical difference was observed between the groups (Table 2).

In relation to the isolated species, $C$. albicans was the most frequently found species in both groups $155 \%$ of the isolated species in the group treated with corticosteroids and 38\% in the control group). No statistically significant difference was observed in the proportion of $C$. albicans and the other species between the studied groups (Table 3).

The other isolated species were C. guilliermondii, C. parapsilosis and C. stellatoidea. Among the children users of inhaled corticosteroids the presence of C. lusitaniae and Rhodotorula rubra was also observed.

There was no statistical significant difference between the mean of $\mathrm{cfu} / \mathrm{ml}$ of saliva in the group treated with corticosteroids $(780 \mathrm{cfu} / \mathrm{ml})$ and that in the control group (560 cfu/ml) (Mann-Whitney's test, $\mathrm{p}=0.251$ ).

In the group of patients treated with inhaled corticosteroids, no correlation was observed between the number of colony-forming units of Candida per $\mathrm{ml}$ of saliva $(\mathrm{cfu} / \mathrm{ml})$, dose of medication and time of use (Table 4).

TABLE 2 - Proportion of patients of the corticosteroidtreated and control groups that is positive or negative for Candida spp.

\begin{tabular}{l|c|c|c}
\hline \hline & $\begin{array}{c}\text { Corticosteroid- } \\
\text { treated }\end{array}$ & Control & Total \\
\hline Candida spp. (+) & 13 & 9 & 22 \\
\hline Candida spp. (-) & 17 & 21 & 38 \\
\hline Total & 30 & 30 & 60 \\
\hline \hline
\end{tabular}

No statistically significant difference was observed between the groups $\left(\chi^{2}\right.$ test; $\left.p=0.284\right)$.

\section{DISCUSSION}

Among the children included in the control group, 30\% were positive to Candida. This observation is in accordance with the findings of Shaw, Edmunds $^{20}$ (1986), who reported a percentage of $29 \%$ children. On the other hand, Berdicevsky et al. ${ }^{1}$ (1984) observed $45-65 \%$ of Candida-positive children. Ollila et al. ${ }^{14}$ (1997), studying children with similar ages in relation to those included in the present work, reported 19\% of Candida-positive individuals.

When data of the two studied groups were compared, it could be observed that among patients treated with inhaled corticosteroids the percentage of Candida-positive patients was higher (43.33\% and 30\%, respectively). Nevertheless, no statistically significant difference could be detected between the groups.

In the present study, $43.33 \%$ of the patients treated with inhaled corticosteroids were positive to Candida in the saliva. Previous studies regarding the incidence of Candida in inhaled corticosteroid-treated patients reported divergent results. Shaw, Edmunds ${ }^{20}$ (1986) observed a higher incidence of Candida in the group of children treated with inhaled corticosteroids in relation to the control ones (43\% and 29\%, respectively). Knight, Fletcher $^{8}$ (1971) also observed higher prevalence among patients treated with corticosteroids (prednisone). On the other hand, Lenander-Lumikari et al. ${ }^{11}$ (1998) did not detect any difference between counts of Candida in asthmatic adults users of inhaled corticosteroids.

Considering the isolated species, C. albicans was the most prevalent one in both groups. This observation agrees with the findings of several previous studies ${ }^{6,7,15,26,28}$. No significant statistical difference was observed between the proportion of

TABLE 3 - Percentage of Candida albicans and other species isolated among the patients of the corticosteroid-treated and control groups.

\begin{tabular}{l|c|c|c}
\hline \hline & $\begin{array}{c}\text { Corticosteroid- } \\
\text { treated }\end{array}$ & Control & Total \\
\hline C. albicans & 11 & 5 & 16 \\
\hline Other species & 9 & 8 & 17 \\
\hline Total & 20 & 13 & 33 \\
\hline \hline
\end{tabular}

No statistically significant difference was observed between the groups $\left(\chi^{2}\right.$ test; $\left.\mathrm{p}=0.353\right)$. 
Komiyama EY, Ribeiro PM, Junqueira JC, Koga-Ito CY, Jorge AOC. Prevalence of yeasts in the oral cavity of children treated with inhaled corticosteroids. Braz Oral Res 2004;18(3):197-201.

TABLE 4 - Number of colony-forming units of yeasts per $\mathrm{ml}$ of saliva $(\mathrm{cfu} / \mathrm{ml})$, dose and time of treatment with corticosteroids.

\begin{tabular}{|c|c|c|}
\hline $\begin{array}{l}\text { Cfu/ml of } \\
\text { yeasts }\end{array}$ & Dose/day ( $\mu \mathrm{g})$ & $\begin{array}{c}\text { Time of } \\
\text { treatment } \\
\text { (months) }\end{array}$ \\
\hline 0 & 100 & 4 \\
\hline 0 & 150 & 2 \\
\hline 400 & 500 & 24 \\
\hline 0 & 400 & 7 \\
\hline 0 & 400 & 3 \\
\hline 1,700 & 100 & 18 \\
\hline 0 & 100 & 9 \\
\hline 0 & 250 & 12 \\
\hline 0 & 400 & 2 \\
\hline 200 & 400 & 4 \\
\hline 100 & 100 & 24 \\
\hline 200 & 400 & 4 \\
\hline 2,400 & 1,200 & 96 \\
\hline 100 & 400 & 2 \\
\hline 0 & 400 & 5 \\
\hline 1,500 & 800 & 3 \\
\hline 200 & 400 & 6 \\
\hline 14,700 & 400 & 2 \\
\hline 0 & 400 & 6 \\
\hline 1,300 & 800 & 6 \\
\hline 400 & 250 & 5 \\
\hline 0 & 400 & 2 \\
\hline 0 & 400 & 8 \\
\hline 0 & 800 & 4 \\
\hline 0 & 400 & 4 \\
\hline 200 & 200 & 6 \\
\hline 0 & 200 & 12 \\
\hline 0 & 400 & 2 \\
\hline 0 & 800 & 48 \\
\hline 0 & 400 & 2 \\
\hline
\end{tabular}

No statistical significance was observed between the $\mathrm{cfu} / \mathrm{ml}$ and dose/day $(\mathrm{r}=0.110 ; \mathrm{p}=0.562)$ and between $\mathrm{cfu} / \mathrm{ml}$ and time of treatment $(r=0.042 ; \mathrm{p}=0.824)$.

\section{REFERENCES}

1. Berdicevsky I, Ben-Aryeh H, Szargel R, Gutman D. Oral Candida in children. Oral Surg Oral Med Oral Pathol 1984;57(1):37-40.

2. Carlsen KH. Inhaled steroids and local side-effects. Allergy 2001;56(10):925-7.

3. Douglas LJ. Adhesion of Candida species to epithelial surfaces. Crit Rev Microbiol 1987;15(1):27-43.
C. albicans and others species between the studied groups.

A higher diversity of Candida species was observed in the group of children under inhaled corticosteroid treatment. In this group, isolates of C. guilliermondii, C. parapsilosis, C. stellatoidea and C. lusitaniae were also found. Besides, Rhodotorula rubra strain was also isolated from these patients. These results are in accordance with previous studies that reported higher prevalence of non-albicans Candida species among patients with other predisposing factors to candidosis ${ }^{7,9}$.

Patients using inhaled corticosteroids are considered at risk for candidosis by many authors ${ }^{4,12,16,19,23}$. The increase in the risk to candidosis has been related to the number, frequency of inhalations ${ }^{21}$ and delivery of the drug without spacer devices ${ }^{16}$. In this study, no significant increase in Candida spp. levels in the oral cavity of children treated with corticosteroids was observed.

\section{CONCLUSIONS}

- No significant increase in Candida spp. in the oral cavity of children treated with inhaled corticosteroids was observed.

- C. albicans was the most frequently isolated species, in both control and corticosteroidtreated groups.

- Among the children users of inhaled corticosteroids, no correlation was observed between the number of colony-forming units of Candida per $\mathrm{ml}$ of saliva (cfu/ $\mathrm{ml}$ ) and the dose of medication and time of treatment.

\section{ACKNOWLEDGMENTS}

We would like to thank Professor Ivan Balducci, School of Dentistry of São José dos Campos, São Paulo State University, for the statistical analysis of this study. We would also like to thank Dr. Fernando Henrique Vargas Degiovane for the referral of many of the patients.

4. Dubus JC, Margurt C, Deschildre A, Mely L, Leroux P, Brouard $\mathrm{J}$, et al. Local side-effects of inhaled corticosteroids in asthmatic children: influence of drug, dose, age and device. Allergy 2001;56(10):944-8.

5. Ellepola ANB, Samaranayake LP. Inhalational and topical steroids, and oral candidosis: a mini review. Oral Dis 2001;7(4):211-6. 
Komiyama EY, Ribeiro PM, Junqueira JC, Koga-Ito CY, Jorge AOC. Prevalence of yeasts in the oral cavity of children treated with inhaled corticosteroids. Braz Oral Res 2004;18(3):197-201.

6. Jabra-Rizk MA, Falkler WA Jr, Enwonwu CO, Onwujekwe DI Jr, Merz WG, Meiller TF. Prevalence of yeast among children in Nigeria and the United States. Oral Microbiol Immunol 2001;16(6):383-5.

7. Jorge AOC, Koga-Ito CY, Gonçalves CR. Presença de leveduras do gênero Candida na saliva de pacientes com diferentes fatores predisponentes e de indivíduos controle. Rev Odontol Univ São Paulo 1997;11(4):279-85.

8. Knight L, Fletcher J. Growth of Candida albicans in saliva: stimulation by glucose associated with antibiotics, corticosteroids, and diabetes mellitus. J Infect Dis 1971;123(4):371-7.

9. Koga-Ito CY, Unterkircher CS, Watanabe H, Martins CA, Vidotto V, Jorge AO. Caries risk tests and salivary levels of immunoglobulins to Streptococcus mutans and Candida albicans in mouthbreathing syndrome patients. Caries Res 2003;37(1):38-43.

10. Koneman EW, Allen SD, Janda WM, Schreckenberger PC, Winn WC. Diagnóstico microbiológico. $5^{\text {a }}$ ed. Rio de Janeiro: Editora Médica e Científica Ltda.; 2001.

11. Lenander-Lumikari $M$, Laurikainen $K$, Kuusisto $P$, Vilja P. Stimulated salivary flow rate and composition in asthmatic and non-asthmatic adults. Arch Oral Biol 1998;43(2):151-6.

12. Maxwell DL. Adverse effects of inhaled corticosteroids. Biomed Pharmacother 1990;44(8):421-7.

13. Odds FC. Candida infections: an overview. Crit Rev Microbiol 1987;15(1):1-5.

14. Ollila P, Niemela M, Uhari M, Larmas M. Risk factors for colonization of salivary Lactobacilli and Candida in children. Acta Odontol Scand 1997;55(1):9-13.

15. Rego MA, Koga-Ito CY, Jorge AOC. Effects of oral environment stabilization procedures on counts of Candida spp. in children. Pesqui Odontol Bras 2003;17(4):332-6.

16. Salzman GA, Pyszczynski DR. Oropharyngeal candidiasis in patients treated with beclomethasone dipropionate delivered by metered-dose inhaler alone and with Aerochamber. J Allergy Clin Immunol 1988;81(2):424-8.

17. Samaranayake YU, Samaranayake LP. Experimental oral candidiasis in animal models. Clin Microbiol Rev 2001;14(2):398-429.
18. Sandvén P. Laboratory identification and sensitivity testing of yeast isolates. Acta Odontol Scand 1990;48(1):2736.

19. Sharma KC, Stevens D, Casey L, Kesten S. Effects of high-dose inhaled fluticasone propionate via spacer on cell-mediated immunity in healthy volunteers. Chest 2000;118(4):1042-8.

20. Shaw NJ, Edmunds AT. Inhaled beclomethasone and oral candidiasis. Arch Dis Child 1986;61(8):788-90.

21. Smith MJ, Hodson ME. High-dose beclomethasone inhaler in the treatment of asthma. Lancet 1983;1(5):2659 .

22. Toogood JH, Jennings B, Greenway RW, Chuang L. Candidiasis and dysphonia complicating beclomethasone treatment of asthma. J Allergy Clin Immunol 1980;65(2):146-53.

23. Walsh LJ, Wong CA, Oborne J, Cooper S, Lewis AS, Pringle $\mathrm{M}$, et al. Adverse effects of oral corticosteroids in relation to dose in patients with lung disease. Thorax 2001;56(4):279-84.

24. Warner JO, Naspitz CK. Third International Pediatric Consensus statement on the management of childhood asthma. International Pediatric Asthma Consensus Group. Pediatr Pulmonol 1998;25(1):1-17.

25. Webb BC, Thomas CJ, Willcox MD, Harty DW, Knox KW. Candida-associated denture stomatitis. Aetiology and management: a review. Part 1. Factors influencing distribution of Candida species in the oral cavity. Aust Dent $\mathrm{J}$ 1998;43(1):45-50.

26. Williams DW, Lewis MAO. Isolation and identification of Candida from the oral cavity. Oral Dis 2000;6(1):3-11.

27. Williamson IJ, Matusiewicz SP, Brown PH, Greening AP, Crompton GK. Frequency of voice problems and cough in patients using pressurized aerosol steroid preparations. Eur Respir J 1995;8(4):590-2.

28. Zöllner MS, Jorge AO. Candida spp. occurrence in oral cavities of breastfeeding infants and in their mothers' mouths and breasts. Pesqui Odontol Bras 2003;17(2):151-5.

Received for publication on Dec 03, 2003

Sent for alterations on Mar 16, 2004 Accepted for publication on May 26, 2004 